2. Ажикова А.К., Цибизова А.А., Фельдман Б.В., Пустохайлов И.В., Самотруева М.А. Изучение регенерирующего действия наружного средства на основе экстракта травы Астрагала лисьего (Astragalus vulpinus willd) // Астраханский медицинский журнал. - 2018. - Т. 13. - № 2. - С. 65-73.

3. Брынцева И.А., Самотруева М.А., Цибизова А.А. Разработка средства для волос на основе "Тинакской" лечебной грязи Астраханской области // Успехи современного естествознания. 2014. - № 5. - С. 190.

4. Зволинский В.П., Рыбашлыкова Л.П. Опыт интродукции лекарственных растений в астраханской области // Аграрный вестник Урала. - 2014. - № 1 (119). - С. 13-16.

5. Качалина Т.В., Мизина П.Г., Джавахян М.А., Семкина О.А. Современное состояние разработок лекарственных средств на основе фитосубстанций в ВИЛАР// Фармацевтический бюллетень. 2016. - № 1-2. - С. 53-57

6. Пупыкина К.А., Гибадуллина О.А., Улямаева Д.Р., Пупыкина В.В., Шайдуллина Г.Г. Фитохимическое изучение алтея лекарственного из флоры Башкортостана // В сборнике: Фармацевтическое образование, наука и практика: горизонты развития. Материалы Всероссийской научно-практической конференции с международным участием, посвященной 50летию фармацевтического факультета КГМУ. Под редакцией В.А. Лазаренко, И.Л. Дроздовой, И.В. Зубковой, О.О. Куриловой. - 2016. - С. 513-515.

7. Самылина И.А., Сорокина А.А., Пятигорская Н.В. Алтей лекарственный (Althaea officinalis 1.) // Фарматека. - 2010. - № 4 (198). - С. 77.

8. Селимзянова Л.Р., Вишнёва Е.А., Федосеенко М.В., Промыслова Е.А. Фитотерапия: современное состояние вопроса // Педиатрическая фармакология. - 2016. - Т. 13. - № 5. - С. 488-493.

9. Цибизова А.А., Убушиева Б.В. Определение полисахаридов травы алтея лекарственного, произрастающего на территории Астраханской области // В сборнике: Фармацевтические науки: от теории к практике. Заочная научно-практическая конференция с международным участием. 2016. - C. $150-152$.

\title{
Lavrinenko E.V., Makhinova O.V. \\ Analysis of special terms of histology and embryology (based on the materials of English and Latin languages)
}

Voronezh State Medical University named after N.N. Burdenko (Russia, Voronezh)

doi: $10.18411 / \mathrm{lj}-08-2020-45$

idsp: ljournal-08-2020-45

\section{Аннотация}

Рассмотрены специальные медицинские термины, различные процессы терминообразования медицинской профессиональной лексики. Анализ и результаты исследования терминов могут быть использованы в практике при изучении клинических дисциплин.

Ключевые слова: специальные медицинские термины, терминоэлементы, эпонимы, гистология, эмбриология.

\section{Abstract}

Special medical terms and various processes of term formation of medical professional vocabulary are examined. The analysis and results of the study of terms can be used in practice while studying clinical disciplines.

Keywords: special medical terms, term elements eponyms, histology, embryology.

The main task of this research article is to identify general patterns of the most common models formation among special medical terms. The study includes terms taken from medical dictionaries and textbooks on histology and embryology.

The structural classification of special medical terms in histology and embryology is represented by the single-word nomination, multi-word nomination and multi-component terms and eponyms. Terms in this article are presented in English and Latin languages, analyzed and described.

In histology and embryology single-word terms consist of Greek-Latin term elements the knowledge of which helps to understand the essence of processes occurring in the 
development of the embryo, and congenital embryonic diseases, explain the composition of tissues and cells. Primarily, we worked with transliteration terms (mostly, these are the names of the cells and clinical terms).

Delamination, Delaminatio, onis f (de - separation, elimination, removal, top-down movement, end of action + lamina plate, layer). The formation of gastrula as a result of the division of the blastoderm into two layers (internal and external).

Teleangiectasia, ae $\mathrm{f}$ (tele - distant, termination + angio - vessel + ectasia -extension, hollow organ expansion). Persistent capillary dilation, vascular tumor in the form of a spot or stripe.

Persistention, Persistentio, onis f (from lat. persisto - permanently abide, stay). Preservation of embryonic structures that disappear by a certain period during normal development.

Hypospadia, ae f (hypo-under, below + spadon - hole) - the lower cleft of the urethra, urethra opening displacement to the lower surface of the penis.

Cheiloschisis, is f (cheilos - lip + schisis - cleavage, cleft). A defect in the upper lip tissue that runs from the red border to the nose. It is often accompanied by the cleft palate and an alveolar process defect.

Aponeuroses (Greek, apo - from, far from + neuro - the original meaning of the word neuron was a vein, tendon and only later - a nerve. A flat, wide tendon formed from dense collagen and elastic fibers.

Osseomucoidum, i n (osteo - bone + lat. nexus-connection). Glykoprotein synthesized by osteoblasts (bone tissue embryos). A large amount is contained in bone tissue.

Chondronectinum, i n (Greek chondros - a seed, cartilage + latin nexus-connection). Adhesive glycoprotein of the intercellular substance fo cartilage tissue, which affects phosphorus-calcium exchange.

Calmodulinum, i n ( Latin calcium-calcium + modulatio - dimension). A calcium binding regulatory protein that is present in all eukaryotic cells.

Myosatellitocyti (Greek - mys, myos - muscle + Latin - satellis - satellite, guard + Greek cytos, kytos - cell). Poorly differential cells involved in the regeneration of striated skeletal muscle fiber.

Oligodendroglia, ae f ( Greek- oligo-small + Dendron-tree + glia-glue). A type of microglia of the Central nervous system which cells surround neurons' bodies and their processes, forming myelin sheaths.

Baroreceptor, oris $m$ (Greek baros - heavy; Latin receptor-receiver from recipere - to take, to receive). Sensitive nerve endings that sense pressure changes.

Pain receptor, Nociceptor, oris $m$ (Latin nocens - harmful, recipere - to take, to receive).They are sensitive nerve endings that sense pain.

Multi word terms of histology and embryology are of great importance in the nomination of processes occurring with intracellular elements and tissue structures. As a rule, a single word term (a noun, an adjective) consisting of Greek term elements is involved in the formation of such terms. A multicomponent term contains a transliterate, most often it is an adjective. Students understand the meaning of such adjectives based on the knowledge of Latin and the basics of medical terminology. We have conducted a detailed analysis of such terms with the purpose to show general patterns of common models construction, their structure for further use in the study of clinical disciplines.

Appositional growth of cartilaage Germinatio cartilaginis appositionis (Latin. apposition-overlay, layering from ad - to + ropege - to put, to add). Growth of cartilage occurring from its periphery.

Interstitial growth of cartilage Germinatio cartilaginis interstitialis. Synonym: Intratissue growth of cartilage. Cartilage increase due to the replication of young cartilage cells located inside. 
Ectopic bone formation, Osteogenesis ectopica (Greek ec - out of, from + topos location). The process of bone tissue formation in an atypical for it place. Actin myofilaments, Myofilamenta actinosa (Greek. mys, myos - a muscle + Latin filamentum thread, fiber; actin - Latin. aktus -movement; another interpretation-from Latin. actis - ray).

Amplification of genes, Amplification genorum, Amplificatio genorum (Latin. amplification - multiplication, increase; Greek. genos - genus). The process of forming multi repeated numerical sequences of DNA copies by repeatedly initiating DNA synthesis in the same replication site. [1, 2].

Locus of the chromosome, Locus chromosomatis (Latin locus - place). The section of the chromosome that contains a specific gene. Perinuclear space, Spatium perinucleare. (Latin. Spatium - space; Greek. peri - about, near around + Latin. nucleus - the core of the nut). The space between the outer and inner core membranes. Most often, in embryology, multi word terms are the names of parts of the embryo, diseases, or processes that occur with pre-germ cells.

Infectious pemphigus of newborns, [4] Pemphigus neonatorum contagiosus (Greek. pemphigus - pemphix - bubble). Pemphigus in the narrow sense-severe dermatosis accompanied by the formation of blisters on the skin and mucous membranes.

Denudation of the ovum, Denudatio ovi (de - negation, separation, break + nudo axpose, bare). The process of exposing the egg from the follicular cells when passing through the oviducts. Extrophy of the bladder, Extrophia vesicale (Extrophy; ex-movement from + trophy - nutrition; vesicale - urogenital) - a congenital cleft of the bladder and abdominal wall. The defect is manifested by a defect in the anterior abdominal wall, through which the exposed mucous membrane of the posterior wall of the bladder turns out.

Important components of histology are eponymic terms. They contain the name of the structure, carry the reference to its discoverer or researcher, which doesn't allow us to forget the names of scientists or doctors.

Incisio myelini (Latin. incision - incision; myelinum - T). Synonym: SchmidtLanterman Notch. Light areas formed as a result of spiral layering of the myelin membrane. Viktor Karlovich Schmidt is a Russian physician, zoologist and the main Russian specialist in microscopic anatomy and embryology. Lanterman August held the position of the head of the Anatomical institute in Strasburg, worked in Cleveland, studued the fine structure of the peripheral nerves [1].

Ranvier's nodal intercept, Nodus neurofibrae Ranvier. Areas where the myelin sheath and neuriliemna in the myelin nerve fiber are completely absent. Louis Antoine Ranvier is a French anatomist and histologist who discovered Ranvier nodes or interceptions in the peripheral and Central nervous system in vertebrates [1,2].

Krause's end flask, Kolba terminalis Krause (German: Kolben glass vessel; SYN. End bulb; Bulbus terminalis) A type of sensitive encapsulated nerve endings. Wilhelm Krause is a German anatomist and histologist.

Thus, the terminological system of histology and embryology is represented by singleword, multi-word and multi-component terms and eponyms. One-word terms are constructed using term elements according to the rules of term formation. For verbose terms, multicomponent is a characteristic feature. In the structure of such terms, in addition to the defining noun, the presence of transliterate (usually an adjective) is revealed. Some terms have two transliterations at once, this is the main noun and the explanatory adjective. Transliteration, in its turn, consists of term elements. Eponymous terms are always verbose terms with proper nouns.

Analysis of special terms shows the necessity and importance of understanding the structure of medical terminals, the rules for its formation. Since ancient times, foreign language vocabulary has been a part of such languages as ancient Greek and Latin. In modern languages, the number of borrowings has increased, especially in scientific and technical vocabulary. It is built almost exclusively on Greek and Latin words thanks to such traditional 
means of word formation as the addition of stems and the use of prefixes, as well as thanks to the age-old traditions of various Greek schools of medicine [5]. Knowledge of the lexical, grammatical and derivational foundations of Latin terminology is necessary in the study of clinical disciplines. [6]

$$
* * *
$$

1. Большой медицинский словарь онлайн [Электронный ресурс]: - Режим доступа: http://www.medslv.ru, свободный доступ.

2. Словарь терминов по общей гистологии, цитологии и эмбриологии// О.Д. Мяделец, Т.Н. Кичигина, Н.Я. Мяделец. - Витебск: ВГМУ, 2007.- 120 с.

3. Anthony L. Mescher, Junqueira's Basic Histology: Text \& Atlas (12th ed.), McGraw-Hill Medical

4. Акушерство. Латинская терминология и ситуационные задачи // под ред. И.Д. Евтушенко. Томск: СибГМУ, 2012. - 95 с.

5. Паринов В.А. Особенности функционирования иноязычной лексики в специальном медицинском дискурсе/ В.А. Паринов, О.В. Махинова // Профессиональное лингвообразование: мат-лы 7 межд. науч.-практ. конф./науч. ред. Н.Л. Уварова, Т.Г. Рыбалко. 2013. -С. 400-403.

6. Махинова О.В. Межпредметная интеграция в медицинском вузе / Махинова О.В., Повалюхина Д.А., Лавриненко Е.В. // В сборнике: Актуальные вопросы высшей медицинской школы. Материалы научно-практического семинара. 2020. С. 71-73. 